\title{
Tuan Husain Kedah: His Influence and Contribution in Islamic Education and Development in Kedah
}

\author{
Napisah Karimah Ismail \\ Universiti Kebangsaan Malaysia \\ Email: napisah@ukm.edu.my \\ Farid Mat Zain \\ Universiti Kebangsaan Malaysia \\ Email: farid@ukm.edu.my
}

Doi:10.5901/mjss.2014.v5n29p62

\begin{abstract}
Tuan Husain Kedah was a renowned local scholar who contributed greatly to the field of Islamic education in Malaysia. He was a prolific author of books and founded the pondok (literally means hut) institution. This article attempts to highlight his role in and contribution to the development of Islam in Malaysia, particularly in the state of Kedah. This study adopts the qualitative approach through analysis of books and related printed material. Research findings show that Tuan Hussain played a big role and made an important contribution to shaping Islamic education in kedah, particularly in the founding of the pondok educational institution. In addition, he was also influential in society because of his role, as a preacher and prolific writer, in providing a better understanding of Islam to the general public. The objective of this research is to study his personality, his educational background, his role as a preacher and educationist as well as his writings. This research encompasses his thoughts, attitude and principles which have made an impact on the society of his time.
\end{abstract}

Keywords: Tuan Husain; Islamic education; Kedah scholar; prominent educationist;

\section{Introduction}

Tuan Husain Kedah or his real name, Husain bin Muhammad Nasir bin Muhammad Taib al-Mas'udi, was a scholar who was not only renowned and loved to serve the society throughout his lifetime, but also left a legacy after him to this day. In his time under British colonial rule, the Muslim society was thirsty for Islamic education and knowledge. Tuan Husain's earnestness in delivering and spreading Islamic knowledge to society can be seen in aspects such as the founding of the pondok educational institution, his writings, teaching and preaching. His leadership qualities, personality and principles in life showed the qualities of a prolific scholar earning him the high esteem and respect of society. This research focuses on previous studies such as by Abdul Garni (1977), Mohd. Rejab (1991 \& 1993), Saleh (1996) and others which have highlighted his background and the books he wrote. Thus, this paper discusses his contribution and role in the development of Islam in Kedah, particularly in the field of education, writing, thinking and principles as well as his general attitude which made an impact on society during his lifetime and afterwards.

\section{Background of Tuan Husain}

Tuan Husain was born in Titi Gajah, Kedah on 20 Jamadil Awal 1280H/2 November 1863. He was a sixth generation descendant of the great scholar, Shaykh Muhammad Arshad bin Abdullah al-Banjari, author of the book Sabil alMuhtadin, who was also the adopted son of Sultan Khamidullah (Sultan Kuning), ruler of Mertapura, Banjar Masin (Saleh, 1996; Rusydi, 2007). According to Rusydi (2007), Shaykh Muhammad Arshad was reported to be descended from Prophet Muhammad PBUH. The first individual from this family who came to Kedah was Haji Mas'udi bin Qadi Muhammad Said. His arrival was unplanned, a destiny determined by Allah SWT when the ship he sailed in stopped by at Kuala Kedah on a return journey to Mertapura, Banjar Masin after pilgrimage. This ship, thought to be a vessel from dari Siam (Thailand) which was on hostile terms with Kedah, was detained and investigated. Satisfied that Haji Mas'udi was not an enemy of Kedah, Sultan Ahmad Tajuddin Halim Shah of Kedah then appointed him to be the Panglima Perang Kedah (army commander of Kedah) after knowing that he was skilled in worldly knowledge. Thus his family 
began to settle in Kedah. However, Haji Mas'udi was killed at Sungai Kedah in the Kedah-Siam war of 1826 when Kota Kuala Kedah was invaded and annexed by Siam (Saleh, 1996; Saman, 1993).

Tuan Husain was known as 'Cik Megat' when he was small because his father, Haij Muhammad Nasir, was married to Tengku Fatimah binti Tengku Mahmud, a member of Kubang Pasu royalty of Kedah. According to customary tradition, a child born from marriage of a commoner to a royal woman will be given the title of 'Megat'. The offspring from this marriage was six in number, four boys including Tuan Husain and two girls.Tuan Husain's father was also a scholar and army commander who loved to travel, trade and preach in the vicinity of the Malay Archipelago (Saleh, 1996).

Since small, Tuan Husain was brought up by his grandfather, Haji Muhammad Taib bin Haji Mas'ud, also a renowned scholar in Kedah at the end of the 19th century and also Mufti of Kedah state during the rule of Sultan Ahmad Tajuddin Mukarram Syah (1854-1879). Haji Muhammad Taib founded a pondok school at Titi Gajah in the year 1870. Besides teaching, he also wrote several books on religion. Tuan Husain was taught religious knowledge and Arabic language until he mastered it well. When he reached 19 years of age in the year 1881, he had gone on foot all the way to Patani to study there. One of his teachers was Tuan Samela, a pondok teacher who was also once his grandfather's teacher. Next, he travelled to Kelantan and lived there for a while. There, he visited pondok schools managed by famous teachers of that time such as Tok Khurasan, Tuan Tabal, Tuan Padang and Tok Qunuk (Awang, 2001; Mohd. Rejab, 1993).

In the year 1883, Tuan Husain travelled to Terengganu in a tongkang (barge). There, he stayed with his cousin doing village jobs to save some money for further travel. After a year, he sailed to Singapore and worked as a labourer to earn a livelihood. About the year 1886, he travelled to Johore and then moved on to Malacca overland. From Malacca, he took a tongkang to Medan, Indonesia and continued to Acheh or Batu Bara. In Acheh, he studied for a few months and was forced to go back to Malacca. From Malacca, he headed to Selangor and then to Perak on foot. In Perak, he stayed for a while at Sungai Rebana and later moved to Sungai Durian on the invitation of Tuan Haji Muhammad Hasan, a prominent scholar at Hilir Perak. There, he taught al-Qur'an to the local children.

While at Sungai Durian, Tuan Husain settled down in marriage to Jaharah, daughter of Penghulu Abdul Wahab. After begetting two children, however, Jaharah passed away and later the children also died. On his return to Titi Gajah, he helped his grandfather in teaching, and was married off to Wan Khadijah binti Wan Jusoh who bore him two children, Ni'matullah Ahmad and Siti Mariam (Mohd. Rejab, 1993). After about two years, in 1892, he departed for Mecca to continue his study under the sponsorship of his grandfather. In Mecca, he studied under Shaykh Omar Sembawa, Shaykh Nawawi Bintan, Ahmad Lingga and Shaykh Hasbullah. It was said that among his close friends in Mecca, were Haji Muhammad Yusof Kelantan or better known as Tok Kenali and Haji Wan Sulaiman bin Wan Sidik (Pak Wan Sulaiman) (Saman, 1993).

Tuan Husain once experienced a bitter incident in his life. In 1929, he had received a letter from Tunku Mahmud who ordered him to leave Kedah immediately. The reason was that he had re-published a book entitled Hidayat alMutafakkirin which was published earlier in 1918 with the permission of Raja Muda Perak, Raja Abdul Aziz, without the permission of Shaykh al-Islam of Kedah, namely Haji Wan Sulaiman. By virtue of a provision in the Shariah Courts of that time, it was prohibited for anyone to publish any religious books or materials without the prior consent of the Shaykh alIslam or his authorized representative. In addition, religious teachers must have the approved credentials for teaching in class. Tuan Husain was reported to have vociferously objected to Haji Wan Sulaiman's action in teaching tariqah to anyone, which Tuan Husain considered inappropriate. Besides that, there were other problems which showed that he and Haji Wan Sulaiman had their differences.

Upon receiving the letter from Tunku Mahmud, Tuan Husain took the decision of moving to Pokok Sena, Seberang Perai. He bought a piece of land and later opened a pondok school and resided there. When Haji Wan Sulaiman passed away on 2 May 1935, Tunku Mahmud visited Tuan Husain in Pokok Sena and invited him to return to Kedah. However, he refused. Moreover his ill-health did not permit him to do so. Later, on the insistence of his daughter, Hajjah Mariam, he agreed to return to Padang Lumat. Tunku Abdullah, son of Tunku Mahmud, who was once his student, fetched him at Pokok Sena and reached Padang Lumat on 6 February 1936M. Four days later, on 10 February 1936, Tuan Husain heaved his last breath. At first, Tunku Mahmud had made preparations to bury him at the burial ground of Makam Diraja Langgar, nearby the cemetery of his grandfather, the late Haji Muhammad Taib. However, Hajjah Mariam stated that Tuan Husain had stated in his will that he should be buried at the burial ground of Titi Gajah. His age at death was calculated to be 72 years, or 74 Hijra years (Mohd. Rejab, 1993; Saleh, 1996).

\section{Role and Contribution}

As a prominent scholar of his time, Tuan Husain had played a big role in Islamic education through the establishment and 
development of the pondok school, writing books relating to religious knowledge and Arabic language as well as making contributions of thoughts and ideas to several issues at once showing his principles and attitude as a true educationist (Mohd. Rejab, 1991). His deeds and contributions that he had sown had benefitted society in understanding and internalization of Islamic teachings.

\section{Establishment of Educational Institution (Pondok)}

Tuan Husain was a scholar who emphasized on religious education in society. It was reported that he founded the pondok educational institution. The uniqueness in his knowledge activities is that he did not stay put in one place, unlike other scholars of his time. It was said that he moved place as many as six times between the years 1897 and 1935. In each place that he stayed, he would open a pondok school and teach the local society there. On his return from Mecca, he taught at the pondok school founded by his grandfather at Titi Gajah. After a year there, he migrated to another place. He first migrated in the year 1897, from Titi Gajah to Alor Ganu situated across the river from Titi Gajah. It was at the invitation of the local inhabitants that he taught them and it was said that he taught Jawi to the villagers before teaching them religious knowledge.

Three years later in the year 1900, he moved to Bohor and resided there for 13 years. It was the longest period for him to stay in a single place in the history of teaching at his own pondok school. The area of the school compound was quite big and it was said that it consisted of 300 pondok or huts. Abdul Garni (1977) estimated that there were about 600 students and a number of them came from Patani, Indonesia and other states in the Malay Peninsula. He himself managed this pondok school without any state government financial provisions. These pondok or huts were of two kinds, inner pondok for married students and outer pondok for single students. His fame led Tunku Mahmud, the Sultan's deputy, to study there every weekend. The latter also placed his son, Tunku Abdullah to stay and study under Tuan Hussain. Among his renowned students were Shaykh Ismail Hamzah, former Mufti of Perak and Shaykh Idris al-Marbawi, author of Qamus al-Marbawi, an Arabic-Malay dictionary (Saleh, 1996).

In the year 1912, he then moved to Bagan Ulu, now known as Pantai Merdeka, and bought land 160 relungs in area. On it, he opened a pondok school which served a student population of up to 400 people. He taught from morning to noon, and was replaced in the afternoon and evening by his assistant, Haji Abdul Ghani, who later became his son-inlaw. Some of his prominent students were Haji Abd. Rahman bin Haji Abdullah, Dato' Murshid DiRaja Kedah, Haji Ismail bin Sulaiman, Tuan Guru Pondok Batu Hampar, Merbok, Kedah and Haji Ghazali bin Haji Arshad, Principal of alIrshadiah al-Diniyah School, Bagan Datok, Perak (Saleh, 1996).

After about seven years, in the year 1920, he made a decision to move to Selengkoh, mukim Sungai Limau and served there for four years. The total number of pondok or huts there was not more than 50 . However, he found the muddy land there unsuitable for it caused many people difficulty to go there. So in the year 1924, after returning from pilgrimage, he moved to Batu Enam Belas, Padang Lumat. There he taught the villagers every Wednesday morning, besides teaching daily in the pondok school. It was said that there were 40 pondok or huts on this site. This school later expanded and developed into what is today a religious school known as Madrasah al-Taufigiah al-Khairiah.

His last migration was in the year 1929, from Padang Lumat to Pokok Sena, Kepala Batas, Seberang Perai after he received a letter ordering him to leave the state of Kedah. It was reported that 100 pondok or huts were built in the school compound and he also built a longhouse as a hostel for 60 students. In terms of learning, he began to use a time table in the year 1934 and with this system, he was able to attract more students. Pokok Sena, at first a small village had grown after the arrival of Tuan Husain. This institution founded by him increasingly progressed and his son, Haji Ahmad, had continued his struggle after Tuan Husain passed away in the year 1936. It is now a school known as Madrasah alKhairiah al-Islamiah and has produced many students such as Ustaz Haji Abd. Hamid Afendi, Ustaz Haji Suhaimi Haji Sulaiman, Ustaz Ishak Manaf, Ustaz Ismail Hashim, Ustaz Othman Fauzi Abd. Rahman, Ustaz Haji Abdul Kadir Haji Hamzah, Ustaz Abu Bakar Kassim, Ustaz Ishak Rejab and Ustaz Mohd. Zain Haji Othman, who all played a big role in the development of Islam after they furthered their education in Mecca, Egypt and India (Awang, 2001).

It can be said that each study centre established by him received an encouraging response and became the focus of those who wished to study or go deeper into religious science and Arabic language. His qualities of piety, decisiveness and his wide knowledge succeeded in attracting the interest of many people to study under him and they came from not only within Kedah, but from distant places such as Patani, Indonesia, Brunei and other states. In spite of the difficult system of communication of that time, and lack of institutions of learning established by the colonial government, these challenges did not dampen his spirit.

The main attraction of the institution established by him was the pondok school, which was not only a place of teaching students residing there, but also open to the villagers in the vicinity to gain deeper Islamic knowledge. In 
addition, he also prepared a timetable for his students as well as encouraged them to earn a livelihood independently. He also taught them from the afternoon, encompassing the time for the obligatory prayers of Zuhr and Asr collectively. His assistants would teach in the evenings. The timetable prepared gave the opportunity to pondok students to earn a living in the morning as a number of them worked in the rice-fields with the local villagers in the morning (Abdullah, 2010). Thus, afternoons and evenings was suitable time to focus on their studies.

\section{Author of Religious Books}

Tuan Husain was a scholar who could not only teach, he was also prolific in writing and publishing. The busy tasks of managing pondok schools and teaching did not prevent him from writing and authoring books on religion and Arabic language. He started writing at the age of 25 years, in the year 1887. His works are as follows:

- al-Nur al-Mustafid fi 'Aqa'id ahl al-Tawhid. A book which discusses Tawhid and was completed in the year $1305 \mathrm{H} / 1887$.

- Tamrin al-Sibyan. A book on Tawhid written in the year 1318/1899.

- Hidayat al-Sibyan. A book which discusses tawhid knowledge and Ibadah written in the year 1330/1911.

- Hidayat al-Atfal. A book on Tawhid written in the year 1336/1917.

- Hidayat al-Mutafakkirin. A book on Tawhid written in the year 1337/1918.

- Kasr al-lksir. A Guidebook on knowing oneself written in the year 1340/1920.

- Tadkir Qaba'il al-Qadi. A translation of the book Jawahir al-Bukhari written in the year 1343/1923.

- Bidayat al-Talibin. A book on Tasawwuf which discusses nazar which leads to makrifatullah and was completed in the year 1344/1924.

- Qatr al-Ghaythiyyah.This is a book on Tasawwuf and was written in the year 1344/1924

- Malaqit al-Lamiyah wa al-Shafiyah. A book on Sarf (Morphology) written in Arabic in the year 1345/1925.

- Tafrih al-Sibyan. A book which relates the history of the birth of Prophet Muhammad PBUH written in the year 1346/1926.

- Usul al-Tawhid. A book which discusses knowledge of Tawhid and Figh written in the year 1346/1927.

- Hidayat al-Nikah. An article written on the laws of marriage written in the year 1347/1928.

- Tabsirah li Uli al-Albab. A book on Tawhid written in the year 1351/1931.

- Hidayat al-Ghilman. A book on Tawhid in Arabic and written in the year 1351/1932.

- Majmu'al-La'ali. A collection of question and answer on Fiqh, including rules on and advantages of prayer, wirid and doa written in the year 1352/1933.

- Tanbih al-Ikhwan fi Tadbir al-Ma'ishah wa Taslih al-Buldan. An article relating to daily affairs and national development according to Islam written in the year 1354/1935.

- Bunga Geti. An article which discusses the problems relating to qada' (deferred prayers), written in the year $1354 / 1935$.

The writings of Tuan Husain may be said to be generally centred on the issues relating to knowledge of Tawhid, Figh and Tasawwuf. Even though he wrote two books on tariqah, he himself never said that he was affiliated to any tariqah stream. Out of 18 books, only 3 of them are still in the market, namely, Hidayat al-Sibyan, Hidayat al-Mutafakkirin and Qatr al-Ghaythiyyah, while the other books are kept in the National Library of Malaysia, National Archives of Malaysia (Kedah and Perlis Branches) and in personal collections (Abdullah, 2011). These writings clearly show that Tuan Husain was a prolific scholar and greatly emphasized knowledge. The output of his writings, particularly in Malay language, may be said to be a significant contribution to society which was in need of knowledge at that time.

\section{Implementation of Morals through Thinking and Principles of Life}

As a teacher and scholar, Tuan Husain was firm in educating his students. He held etiquette and discipline as very important such that his students and the villagers were influenced by this attitude and practised courtesy in their demeanour. His students were not allowed to keep long hair, wear pants and black caps. They were also not allowed to smoke, sing, whistle and mix freely between opposite sexes. To avoid free mixing, there were separate living quarters and classes, while pondok for the single and married were also separate. He would ensure that they performed prayers collectively, dressed up modestly with white caps for males and attended lectures as scheduled. Any breach of rules and discipline would be punishable by caning as a lesson for them regardless of age or family name (Abdul Garni, 1977). His sternness in keeping etiquette and discipline succeeded in educating his students to be courteous and noble in 
disposition and respected in society.

Tuan Husain's habitual shifting from one place to another was motivtated by his principle to open and develop more pondok schools. His aim was to spread Islamic teachings and facilitate learning for the public. For that reason, when the residents of a place had become satisfactorily knowledgeable about Islam, he would move to another place where many people needed learning to read and write (Abdul Garni, 1977). This was the principle he adhered to till the end of his days and thus it was not surprising that he shifted place six times during the time he opened pondok schools. This principle clearly showed that he was earnest in educating the public during his time so that they would not only be literate but understood the true Islamic teachings. Aside from teaching in pondok schools, according to Ismail and Mat Zain (2011), Tuan Husain also received many invitations to teach in other places such as the Kuala Kangsar Palace, Bukit Chandan Mosque, Telok Anson (Teluk Intan) Mosque and Parit Mosque in Perak. His coming would be publicized before he reached those places and evidently his lectures met with an encouraging response from the public who flocked to gain knowledge from his lectures.

Tuan Husain was a person who did not expect any gifts, charity or compulsory zakah fitrah from the public for his personal living expenses or to fund his students' pondok settlement. Instead, he himself purchased land and alienated it as public endowment (waqaf) such as for the site of a mosque and cemetery at Titi Gajah, a site for a religious school at Padang Lumat as well as at Pokok Sena, Seberang Perai. Both these schools are still functioning to this day. During his lifetime, he had hundreds of relungs of rice fields, rubber holdings and coconut holdings and it was reported that 150 relungs of land were bequeathed to his grandchildren, aside from other forms of property, after he passed away (Saleh, 1996). His generosity could also be seen in his spending of wealth for welfare such as holding public feasts in the fasting month of Ramadan and on days of Islamic celebration. In addition, he taught the public every Sunday while at Pokok Sena, and usually he would provide lunch for the public when they came for his lecture. His generosity caused him not to like accepting gifts from others, but if he had no choice, he would use the gifts for public interest, particularly for his students (Abdul Garni, 1977).

Tuan Husain was also unequivocal in the struggle for his life principle and did not hesitate to correct something he considered as deviating from the true Islamic teachings. Based on this, he criticized the Shaykh al-Islam, Haji Wan Sulaiman, whom he considered as commiting a mistake in carrying out his religious duties, particularly for allowing the teachings of tariqah Naqshabandiyyah to be taught to anyone, for the ruling on interest money from cooperatives and the method of zakah collection by amils in Kedah at that time. The contradiction in opinions between them had caused a serious conflict to arise to the extent that Tuan Husain was forced to leave the state of Kedah (Saleh, 1996). In addition, Tuan Husain was uncompromising in correcting the faith of Muslims and disregarded political restrictions because his conviction was to do everything for Allah SWT and religion which responsibilities he shouldered (Abdul Garni, 1977). In this matter, he suggested that all adherence to erroneous ittigad (religious doctrines) must be prevented and only the true ittiqad need to be taught, as asserted in his book, Hidayat al-Mutafakkirin (Mohd. Rejab, 1991).

Aside from his thinking and contribution in education and religion, Tuan Husain also made statements on material development. He suggested that the Muslim community engage in commerce and big scale rice-planting projects. However, before engaging in commerce or other economic activity, he asserted the need to learn the ins and outs of the business for without knowledge, experience, skill and so on, a project could not be properly run or achieve its objective.This is stated in his book, Tanbih al-Ikhwan fi Tadbir al-Ma'ishah wa Taslih al-Buldan. The suggestion that people be active in agriculture, particularly rice-planting was because rice was the staple food of Kedah. A big scale rice industry would not only feed the local population, but would be a source of national economy such as in Thailand and India. Apart from agriculture, Tuan Husain also urged Muslims to engage in commerce based on Shariah. He suggested that commercial centres or shopping complexes be opened at strategic places. His suggestions for material development were not deemed as excessive love for the world, because to him, efforts to gain worldly wealth to raise the standard of living by means which do not contradict Allah's Shariah, were not deemed as excessive love for the world, instead it was to improve the economic status of the Muslim community itself (Mohd. Rejab, 1991).

The thoughts he put forward, the principles he upheld and the attitude that he showed clearly gave an impact on society and he frequently suggested and urged the society to endeavour in raising the standard of living in every field of life, regardless of whether it is related to the hereafter or this world.

\section{Conclusion}

In researching the life of Tuan Husain, it may be said that he was a scholar who was tenacious and consistent in his struggle. Since he was young, he had led a difficult life and sought knowledge such as experienced by his peers or his contemporaries. From his perseverance in the pursuit of knowledge, it may be stated that poverty and deprivation do not 
at all deter a person from seeking knowledge. This principle that Tuan Husain adhered to made him consistently pursue hias ambition to educate the public. In every place that he settled in, he would establish a pondok school. His learnedness caused the pondok school to be the focus of the society and students. His efforts had created a conducive atmosphere for education and succeeded to make the society knowledgeable. The tradition of knowledge founded and built by Tuan Husain was further developed by his students and some of the pondok schools still function today, particularly Pondok Padang Lumat, Kedah and Pokok Sena, Pulau Pinang. Hence, the role and great contribution of Tuan Husain deserve to be appropriately acknowleged, emulated by the Muslim society, and duly recognized, particularly in Malaysia and generally in the Malay World.

\section{Acknowledgement}

This study is financed by the Research Group of Arabic Culture and Islamic Civilization (KUKAPI, DPP-2014-068), UKM; the Action/Strategic Research Project (PTS-2012-061; PTS-2014-068), UKM; the University-Industry Incentive Grant (INDUSTRI-2012-006), UKM; and the Arus Perdana Project (AP-2012-001; AP-2013-017; AP-2014-006), UKM.

\section{References}

Abdul Garni, A. (1977). Tuan Husain Kedah, Academic exercise. Department of History, Universiti of Malaya.

Abdullah, N.H. (2010). Tuan Husain Kedah. Retrieved from http://ummatanwasatan.net/2010/10/jiwa-warisan-darah-pahlawan

Abdullah, S. (2011). Sumbangan ulama banjar di Kedah. Retrieved from http://www.kdhlib.gov.my/ wacanal

Awang, I. (2001). Tuan Husain Kedah (1863-1936). In Daud, I. (ed.). Tokoh-tokoh Ulama' Semenanjung Melayu 1. Kota Bharu: Majlis Ugama Islam dan Adat Istiadat Melayu Kelantan.

Ismail, N.K \& Mat Zain, F. (2011). Sumbangan Tuan Husain Kedah terhadap Perkembangan Islam di Kedah. In the Proceeding of Nadwah Ulama Nusantara, p. 345-350.

Mohd. Rejab, I. (1991). Peranan ulama' dalam masyarakat di Kedah dengan diberi penekanan kepada Tuan Husain bin Muhammad Nasir al-Mas'udi dan Haji Wan Sulaiman Wan Sidek, Dokumentasi Konvensyen Sejarah. Lembaga Muzium Negeri, Kedah Darul Aman, Alor Setar, Malaysia.

Mohd. Rejab, I. (1993). Haji Husain Mohd Nasir al-Mas'udi. In Mat, I. (ed.). Ulama Silam dalam Kenangan. Bangi: Penerbit Universiti Kebangsaan Malaysia.

Rusydi, M. (2007). The Influence of Muhammad Arsyad al-Banjari on the Religiosity of Banjarese Society. Al-Banjari, 5(10), 1-19.

Saleh, I. (1996). Tuan Hussain Kedah (1863-1936): Biografi Ulama Kedah Darul Aman. Jil. 1. Alor Setar: Lembaga Muzium Negeri Kedah Darul Aman.

Saman, T. (1993). Tokoh Ulama Nusantara. Kuala Lumpur: Berita Publishing Sdn. Bhd. 